\title{
POZIOM, MOTYWY UTRZYMYWANIA ORAZ FUNKCJE REZERW WALUTOWYCH KRAJÓW ROZWINIĘTYCH ANALIZA ZE SZCZEGÓLNYM UWZGLĘDNIENIEM EUROPEJSKIEGO SYSTEMU BANKÓW CENTRALNYCH
}

\begin{abstract}
Streszczenie. Artykuł koncentruje się na analizie motywów posiadania, poziomu oraz sposobów wykorzystania rezerw walutowych w krajach rozwiniętych, ze szczególnym uwzględnieniem dualnej struktury rezerw w ramach Unii Gospodarczej i Walutowej (UGiW). Rezerwy walutowe krajów rozwiniętych wykazywały w ostatnich latach tendencję wzrostową. Jednakże w przypadku UGiW wzrost ten nie wynikał z intencjonalnych działań banku centralnego (jak w spektakularnych przykładach Japonii i Szwajcarii), lecz z pozytywnych efektów kursowych i stopy zwrotu.
\end{abstract}

Słowa kluczowe: rezerwy walutowe, Europejski System Banków Centralnych.

\section{WPROWADZENIE}

Cechą analizy współczesnego międzynarodowego systemu walutowego (MSW) jest zrelatywizowanie oceny poziomu, motywów utrzymywania i sposobów wykorzystania rezerw walutowych w gospodarkach narodowych. Tradycyjnie stosowaną metodę oceny powyższych aspektów w zależności od przyjętego reżimu kursowego (stały versus płynny) coraz częściej przeciwstawia się zależności od poziomu rozwoju gospodarczego kraju (kraj rozwijający się versus rozwinięty). W przypadku krajów rozwijających się nawet w warunkach reżimu płynnego poziom rezerw staje się parametrem percepcji kraju przez rynki i agencje ratingowe; rezerwy mogą wzmacniać lub osłabiać wiarygodność polityki monetarnej i stabilność finansową kraju.

Rezerwy walutowe krajów rozwiniętych przyciągają jednak mało uwagi w badaniach teoretyczno-empirycznych, w przeciwieństwie do rezerw znajdujących się w posiadaniu krajów emerging markets, prowadzących od lat 90. $\mathrm{XX}$ w. politykę intensywnego, intencjonalnego akumulowania rezerw. Jednak w ostatnich latach, także w grupie krajów rozwiniętych, nastąpił wzrost rezerw

* Uniwersytet Łódzki, Wydział Ekonomiczno-Socjologiczny, Katedra Międzynarodowych Stosunków Gospodarczych. 
- w przypadku niektórych krajów w sposób aktywny, jako wynik nadwyżek płatniczych lub przeciwstawiania się aprecjacji waluty, bądź - w przypadku innych krajów - w sposób pasywny, jako konsekwencja zarządzania portfelem.

Celem artykułu jest prezentacja, na przykładzie Europejskiego Systemu Banków Centralnych i w odniesieniu do doświadczeń innych krajów rozwiniętych - motywów utrzymywania, zastosowania oraz skali i kompozycji portfela rezerw walutowych.

\section{ZASADNOŚĆ POSIADANIA REZERW WALUTOWYCH W PRZYPADKU KRAJÓW EMERGING MARKETS, KRAJÓW ROZWINIĘTYCH ORAZ W WARUNKACH UNII WALUTOWEJ}

Głównym celem utrzymywania rezerw jest możliwość powiększenia podaży dewiz w sytuacji pojawienia się nierównowagi na rynku walutowym (por. Przestanki oceny... 2003). Tradycyjnie jako motywy utrzymywania rezerw walutowych wymienia się:

- zapewnienie wiarygodności finansowej kraju oraz realizacji polityki kursowej kraju,

- zapewnienie płynności płatniczej kraju oraz bezpieczeństwa obrotu dewizowego,

- ochronę przed szokami powstałymi w handlu zagranicznym (zakłócenia w imporcie) i na rachunku kapitałowym (niestabilne przepływy kapitału).

We współczesnej literaturze dotyczącej zjawiska akumulacji rezerw krajów emerging markets powszechnie konfrontuje się ze sobą dwa motywy: przezornościowy (ubezpieczeniowy) i interwencyjny (proeksportowy). Motyw przezornościowy ma na celu łagodzenie wahań gospodarczych poprzez zapobieganie kryzysom. Wahania te mogą wynikać z nagłych ruchów kapitału (zarówno jego gwałtownych odpływów, jak i napływów), syndromu ,zarazy holenderskiej”, zaburzeń w dystrybucji płynności walutowej. Motyw proeksportowy koncentruje się na pobudzaniu wzrostu gospodarczego przez stymulowanie eksportu, dla którego kluczowe jest utrzymywanie niedoszacowanego kursu walutowego.

Naturalne jest, że w przypadku krajów rozwiniętych popyt na rezerwy maleje, co wynika ze wzrostu wiarygodności kraju i związanego z tym mniejszego kosztu pożyczania środków na międzynarodowych rynkach finansowych, a także ze spadku ryzyka ataków spekulacyjnych prowadzących do wstrząsów gospodarczych. W przypadku tej grupy krajów motyw przezornościowy, a więc zabezpieczania się przed niespodziewanymi szokami płynościowymi i zaburzeniami w dostępie do rynków kapitałowych, nie odgrywa już tak istotnej roli, jak w przypadku krajów emerging markets, również ze względu na możliwość uzyskania wsparcia płynnościowego od zagranicznych banków centralnych. Doświadczenia ostatniego kryzysu finansowego wykazały, że kraje te łatwo stają się beneficjentami 
Cel utrzymywania rezerw walutowych w oficjalnych materiałach banków centralnych

\begin{tabular}{|c|c|}
\hline Kraj & Cel utrzymywania rezerw \\
\hline Kanada & $\begin{array}{l}\text { „kontrola i ochrona zewnętrznej wartości dolara kanadyjskiego }[\ldots] \\
\text { zapewnienie płynności w walutach zagranicznych rządowi oraz, jeśli } \\
\text { potrzeba, sprawnych rozliczeń dla transakcji w dolarze kanadyjskim na } \\
\text { rynkach walutowych” }\end{array}$ \\
\hline Wielka Brytania & $\begin{array}{l}\text { „dla celów przezornościowych - w sytuacji zmiany w polityce kursowej } \\
\text { w przyszłości lub w sytuacji wystąpienia niespodziewanych szoków [...] } \\
\text { zapewnienie dostępu do dewiz dla rządu i jego agencji, regulowania płat- } \\
\text { ności dewizowych, zakupu i sprzedaży SDR-ów wynikających z człon- } \\
\text { kostwa w MFW” }\end{array}$ \\
\hline Japonia & $\begin{array}{l}\text { „zapewnienie wystarczającej płynności, aby być przygotowanym dla za- } \\
\text { kupu i sprzedaży walut zagranicznych [...] potrzebnych dla zapewnienia } \\
\text { stabilności waluty japońskiej” }\end{array}$ \\
\hline $\begin{array}{l}\text { Unia Gospodarcza } \\
\text { i Walutowa }\end{array}$ & $\begin{array}{l}\text { „głównym celem utrzymywania rezerw EBC jest zapewnienie, w razie } \\
\text { konieczności, wystarczającej ilości płynnych środków dla operacji walu- } \\
\text { towych, włączając w to waluty pozaunijne" }\end{array}$ \\
\hline Szwajcaria & $\begin{array}{l}\text { „zapewniają zaufanie dla franka szwajcarskiego, służą ochronie przed } \\
\text { kryzysami, mogą być wykorzystywane dla celów interwencyjnych [...] } \\
\text { utrzymując rezerwy w złocie i dewizach, bank centralny zapewnia, że } \\
\text { ma swobodę dla prowadzenia polityki monetarnej w różnych warun- } \\
\text { kach” }\end{array}$ \\
\hline USA & $\begin{array}{l}\text { "operacje walutowe generalnie są nakierowane na przeciwdziałanie nie- } \\
\text { stabilnym warunkom rynkowym" }\end{array}$ \\
\hline
\end{tabular}

Źródło: Goldberg, Hull, Stein (2013).

linii swapowych od innych banków centralnych, co może ograniczać ich popyt na rezerwy. Podobną rolę substytutu rezerw odgrywała Elastyczna Linia Kredytowa (Flexible Credit Line) uruchomiona przez MFW. Łatwość dostępu do walut obcych, powodująca ich substytucyjność względem rezerw, jest czynnikiem obniżającym popyt na nie.

Rezerwy walutowe krajów rozwiniętych służą głównie do przeprowadzania operacji walutowych. Mimo, że kraje te w większości przypadków stosują reżim płynny, posiadanie rezerw walutowych ma za zadanie dać efekt sygnalny uczestnikom rynku o pożądanym przez bank centralny kierunku kształtowania się kursu walutowego. Oprócz tradycyjnej, interwencyjnej funkcji rezerw, odgrywają one - na skutek wzrostu międzynarodowych powiązań banków - funkcję dostarczania płynności walutowej krajowemu systemowi bankowemu. 
Szczególnym przypadkiem funkcjonowania krajów we współczesnej gospodarce globalnej jest unia walutowa - jako jedną z korzyści jej utworzenia wymienia się spadek popytu na rezerwy walutowe. Możliwość utrzymywania niższego poziomu rezerw walutowych lub nawet pozbycia się ich na poziomie narodowym, w wyniku utworzenia unii walutowej posiadającej wspólny system poolingu rezerw, traktowana jest jako istotna korzyść finansowa integracji walutowej, akcentowana w bilansie kosztów i korzyści tej płaszczyzny integracji (pogląd taki wyraża m.in. Wójcik 2005).

W praktyce współczesnych krajów rozwiniętych znaczenie rezerw walutowych w ustawach o banku centralnym oraz w wypowiedziach jego przedstawicieli jest podobnie akcentowane - jako instrument ochrony wartości waluty krajowej oraz zarządzania nadmierną zmiennością na rynku walutowym. W niektórych przypadkach eksponowany jest dodatkowy cel, np. zapewnienie płynności dla zagranicznych operacji walutowych.

\section{POZIOM, KOMPOZYCJA ORAZ WYKORZYSTANIE REZERW WALUTOWYCH PRZEZ WIODĄCE KRAJE ROZWINIĘTE}

Większość krajów rozwiniętych utrzymuje współcześnie niski poziom rezerw, zgodnie z przewidywaniami teoretycznymi. Popyt USA na rezerwy walutowe jest dodatkowo osłabiony faktem emitowania przez kraj waluty rezerwowej. Niektóre z krajów rozwiniętych, jak np. Nowa Zelandia, oficjalnie deklarują, ze względu na wysoki koszt alternatywny ich utrzymywania, jedynie minimalny poziom rezerw jako cel strategiczny banku centralnego (Munro, Reddell 2012: 36). Dodatkowo, czynnikiem niskiego zasobu rezerw w krajach rozwiniętych jest polityka niedostarczania dewiz przez bank centralny dla finansowania płatności sektora prywatnego. Przykładem jest Bank Kanady, który nie prowadzi operacji dewizowych z krajowym sektorem bankowym (por. Bogołębska 2013).

Paradoksalnie jednak poziom rezerw walutowych utrzymywanych przez wiodące kraje rozwinięte w ostatniej dekadzie wykazuje wzrost. Analizując źródła tego wzrostu, należy dokonać podziału tych krajów na dwie grupy:

1. Kraje, w których przyrost rezerw wynikał głównie z fluktuacji kursów walutowych (euro, dolara i jena), zysków kapitałowych i dochodowości z inwestycji posiadanego portfela. W grupie tej znajdują się USA, Kanada, UGiW oraz Wielka Brytania. Przyrost rezerw w ostatniej dekadzie w tej grupie wynosił od 39\% w przypadku EBC do 68\% w przypadku Banku Kanady. Kraje te bardzo rzadko stosują interwencje walutowe. Wyjątkiem była skoordynowana interwencja przeprowadzona 18 marca 2011 r., w celu osłabienia jena po trzęsieniu ziemi i tsunami w Japonii oraz interwencja z 2000 r. mająca na celu wzmocnienie euro. Rzadkie jednak, w stosunku do ustawowego wyeks- 
ponowania, wykorzystywanie rezerw walutowych dla celów interwencyjnych w tych krajach potwierdza, że przyrost rezerw należy przypisywać efektowi wyceny (valuation effect) oraz efektowi wzrostu wartości portfela z inwestycji (growth effect).

2. Kraje, w których przyrost rezerw wynikał z realizowanego celu kursowego $\mathrm{w}$ ich strategiach monetarnych. Zakup walut na rynku walutowym miał na celu przeciwdziałanie aprecjacji waluty krajowej. Wzrost rezerw nie był celem samym w sobie, lecz produktem ubocznym (by-product) realizowanej polityki gospodarczej. Należy tu wymienić Japonię, której rezerwy między 2000 a 2012 rokiem wzrosły o ponad 250\% oraz Szwajcarię, w przypadku której spektakularny wzrost rezerw (o 234\%) następował w wyniku interwencji przeprowadzanych w latach 2009-2011 (były to jednocześnie pierwsze od 1995 r. interwencje walutowe kraju).

Wzrost rezerw Szwajcarii jest zjawiskiem o tyle ciekawym, że nastąpiło ono w stosunkowo krótkim czasie. Aprecjacja CHF rozpoczęła się, gdy nominalne stopy procentowe w innych krajach rozwiniętych spadły, co zawęziło dysparytet ze stopami procentowymi w Szwajcarii i przyczyniło się do ograniczenia roli CHF jako waluty finansowania wykorzystywanej w transakcjach carry trades. Wraz z rozwojem kryzysu zadłużeniowego w UGiW, przepływy funduszy do aktywów postrzeganych jako safe haven dodatkowo generowały presję na aprecjację waluty. Aprecjacja CHF do połowy $2011 \mathrm{r}$. osiągnęła 50\% w stosunku do EUR, $47 \% \mathrm{w}$ stosunku do USD, $33 \% \mathrm{w}$ ujęciu realnym efektywnym. Skłoniło to bank centralny do ustanowienia oficjalnego celu kursowego, określającego minimalny poziom akceptowanego kursu $(1,20 \mathrm{EUR} / \mathrm{CHF})$ jako cel polityki monetarnej banku centralnego, do którego będzie on dążył, przeprowadzając interwencje w nieograniczonej skali.

Wzrost rezerw Japonii jest zjawiskiem o zdecydowanie bardziej długookresowym charakterze (od lat 90. XX w). Akumulując rezerwy, Japonia realizowała strategię walki z deflacją i słabym wzrostem gospodarczym, poprzez kanał silnego wzrostu eksportu.

Oceniając poziom rezerw walutowych krajów rozwiniętych w globalnym zasobie rezerw, należy zauważyć, że na koniec 2009 r. w grupie 17 największych światowych posiadaczy rezerw znajdowało się 6 krajów rozwiniętych. W grupie tej, oprócz analizowanych powyżej wiodących banków centralnych gospodarki globalnej, znajduje się Norwegia, w przypadku której akumulacja rezerw wynika z nadwyżek handlowych pochodzących z eksportu ropy naftowej. Ocena poziomu rezerw walutowych jest trudna ze względu na współwystępowanie wielu miar ich adekwatności i ich ułomności (brak relatywizowania do uwarunkowań poszczególnych gospodarek). Mimo tych słabości, na uwagę zasługuje Japonia, posiadająca ponadoptymalny poziom rezerw według wszystkich powszechnie stosowanych miar adekwatności. 
Poziom rezerw krajów rozwiniętych i ich adekwatność

\begin{tabular}{|c|c|c|c|c|}
\hline \multirow[b]{2}{*}{ Kraj } & \multirow{2}{*}{$\begin{array}{l}\text { Poziom rezerw } \\
\text { (grudzień 2009), } \\
\text { w mld USD }\end{array}$} & \multicolumn{3}{|c|}{ Miary adekwatności rezerw (stan na koniec 2009 r.) } \\
\hline & & $\begin{array}{c}\text { jako pokrycie } \\
\text { miesięcznego importu }\end{array}$ & jako \% M2 & $\begin{array}{c}\text { jako \% } \\
\text { krótkoterminowego } \\
\text { zadłużenia }\end{array}$ \\
\hline Kanada & 43 & 1,6 & 4,8 & 16,2 \\
\hline UGiW & 195 & 1,3 & 1,6 & 3,4 \\
\hline Japonia & 997 & 21,8 & 122,9 & 185,7 \\
\hline Norwegia & 46 & 8,0 & 17,3 & 35,6 \\
\hline Szwajcaria & 91 & 7,4 & 15,2 & 22,5 \\
\hline Wielka Brytania & 38 & 0,9 & 1,2 & 1,6 \\
\hline
\end{tabular}

Miary adekwatności: import: pokrycie 3-4 miesięcy; M2: pokrycie 5-20\%; krótkoterminowe zadłużenie: pokrycie $100 \%$.

Źródło: na podstawie International Monetary Fund, Annual Reports, U.S. Treasury Reports.

Kompozycja walutowa rezerw również zmieniała się na przestrzeni ostatniej dekady, co odzwierciedla globalne tendencje wzrostu dywersyfikacji portfela rezerw. Analizowana grupa krajów rozwiniętych utrzymuje rezerwy walutowe w euro, USD oraz jenie japońskim. Największy zakres dywersyfikacji walutowej posiada Szwajcaria, która w portfelu rezerw utrzymuje także funta brytyjskiego, dolara kanadyjskiego i koronę duńską.

W ostatniej dekadzie nastąpił spadek udziału USD, przy jednoczesnym wzroście udziału euro i jena w portfelu rezerw krajów rozwiniętych. Szczególnie wyraźny wzrost euro w portfelu odnotowała Szwajcaria, co wynika z wspomnianych powyżej, przeprowadzanych intencjonalnych operacji interwencyjnych.

Tabela 3

Udział zagranicznych aktywów w portfelach rezerw banków centralnych (w \%)

\begin{tabular}{|l|c|c|c|c|c|c|c|c|}
\hline \multirow{2}{*}{ Kraj } & \multicolumn{2}{|c|}{ Aktywa w USD } & \multicolumn{2}{c|}{ Aktywa w EUR } & \multicolumn{2}{c|}{ Aktywa w JPY } & \multicolumn{2}{c|}{$\begin{array}{c}\text { Aktywa w innych } \\
\text { walutach }\end{array}$} \\
\cline { 2 - 10 } & 2000 & 2011 & 2000 & 2011 & 2000 & 2011 & 2000 & 2011 \\
\hline Kanada & 49,4 & 60,4 & 47,3 & 39,3 & 3,3 & 0,3 & 0 & 0 \\
\hline Wielka Brytania & 36,2 & 28,3 & 41,9 & 59,1 & 21,9 & 12,6 & 0 & 0 \\
\hline UGiW & 96,0 & 76,9 & - & - & 4,0 & 23,1 & 0 & 0 \\
\hline Szwajcaria & 40,0 & 26,0 & 44,0 & 52,0 & 4,0 & 9,0 & 12 & 13 \\
\hline USA & - & - & 47,0 & 53,0 & 53,0 & 47,0 & 0 & 0 \\
\hline
\end{tabular}

Źródło: Goldberg, Hull, Stein (2013). 
Niektóre z analizowanych banków centralnych mają określony cel alokacji w strategiach dywersyfikacji rezerw. Przykładem jest Bank Anglii, który publicznie ogłosił docelową strukturę alokacji portfela rezerw: 40\% w USD, 40\% w EUR oraz $20 \%$ w JPY. Z kolei alokacja portfela rezerw Banku Kanady jest powiązana $\mathrm{z}$ denominacją walutową pasywów rządowych. W przypadku Banku Japonii, Szwajcarii, EBC nie nastąpiło publiczne udzielenie informacji, czy są stosowane strategiczne cele $\mathrm{w}$ alokacji portfela. USA nie zarządzają aktywnie kompozycją rezerw, ale pozostawiają portfel rezerw w pierwotnie uzyskanym składzie (Goldberg, Hull, Stein 2013: 6).

Bardziej widoczne przeobrażenia w kompozycji rezerw w ostatnich latach zachodzą od strony instrumentów, w których utrzymywany jest portfel rezerw. Wśród czynników prowadzących do globalnej tendencji do dywersyfikacji instrumentów w portfelu rezerw J. Pihlman i współpracownicy wyodrębniają (Pihlman, van der Hoorn 2010: 6-10):

- szybkie tempo przyrostu rezerw, w szczególności po kryzysie azjatyckim, z 1,8 tryl. USD w 1998 r. do 8,5 tryl. USD 11 lat później (rezerwy z wyłączeniem złota),

- niskie stopy procentowe, co doprowadziło do globalnego zjawiska poszukiwania wyższych dochodowości, w którym banki centralne także zaczęły brać udział (global search for yield). Motyw ten powodował, że wiodącym czynnikiem dywersyfikacji były wyższe spodziewane stopy zwrotu, podczas gdy tradycyjny argument przemawiający za dywersyfikacją - redukcja ryzyka - odgrywał mniej istotną rolę. Wpisanie się banków centralnych w strategię search for yield spowodowało tendencję do tworzenia państwowych funduszy majątkowych (Sovereign Wealth Funds - SWF), które szczególnie dynamicznie zaczęły powstawać w trakcie ostatniej dekady,

- nadwyżka budżetowa USA odnotowywana od 1998 r., która według prognoz miała narastać. Podobne prognozy dotyczyły sytuacji budżetowej innych krajów rozwiniętych. Pozwalało to przyjąć przypuszczenie, że rządowe zadłużenie może z czasem istotnie maleć, zatem skłaniało banki centralne do poszukiwania alternatywy dla zadłużenia rządowego,

- profesjonalizacja funkcji zarządzania rezerwami walutowymi banku centralnego i przyjęcie założenia, że powinien on posiadać w swoim portfelu inwestycje w systemowo ważne klasy aktywów (jak np. papiery wartościowe zabezpieczone hipoteką), aby dobrze zrozumieć funkcjonowanie rynku tego typu aktywów.

Zakres instrumentów, w które są inwestowane aktywa zagraniczne krajów rozwiniętych jest różny - Japonia i USA inwestują rezerwy w stosunkowo wąski zakres aktywów, zaś Kanada, Szwajcaria i UGiW prowadzą politykę zwiększania spektrum instrumentów lokowania rezerw, czym wpisują się w bardziej globalny trend zwiększania dywersyfikacji aktywów oraz większego wykorzystywania derywatów finansowych w zarządzaniu portfelem. W ich portfelu znajdują się też takie walory, jak obligacje korporacyjne i akcje. 


\section{SKALA, ZNACZENIE ORAZ KOMPOZYCJA WALUTOWA REZERW WALUTOWYCH W UGIW}

Tworząc bankowość centralną w warunkach UGiW, zastosowano podejście tzw. dualnego systemu rezerw, czyli równoległego posiadania rezerw walutowych przez narodowe banki centralne oraz przez EBC. Konsekwencją utworzenia dwóch komponentów rezerw stał się klarowny podział ich funkcji. Rezerwy EBC spełniają funkcje związane z realizacją polityki pieniężnej i kursowej, a więc zasadnicze funkcje monetarne. Należy pamiętać, że w ramach polityki kursowej Eurosystemu mieszczą się nie tylko walutowe operacje interwencyjne przeprowadzane $\mathrm{z}$ walutami pozaunijnymi, lecz także operacje wynikające z konieczności stabilizowania walut uczestniczących w ERM II. Przypisanie funkcji interwencyjnej tylko części rezerw, stanowiącej pooling rezerw będący w dyspozycji EBC, stanowiło logiczną konsekwencję utworzenia unii walutowej realizującej jednolitą politykę pieniężną. Nie uchroniło to jednak unii przed niejasnościami interpretacyjnymi i wynikającymi stąd konfliktami instytucjonalnymi. Od początku funkcjonowania UGiW był bowiem widoczny konflikt dotyczący kompetencji w zakresie ustanawiania zasad polityki kursowej, a więc także przeprowadzania operacji mających na celu stabilizowanie kursu euro. Konflikt sprowadzał się do zasadniczego pytania: który organ - EBC czy Eurogrupa (,subgrupa” ECOFIN Council, a więc Rady Ministrów Finansów krajów członkowskich) - jest wyposażony w tę kompetencję, który jest nadrzędny? (więcej na ten temat: Henning 2007).

Jak wspomniano, podstawowym celem utrzymywania rezerw walutowych EBC jest zapewnienie Eurosystemowi w razie konieczności wystarczającej ilości płynnych środków przeznaczonych na operacje związane z realizacją polityki walutowej. Tymczasem EBC w swojej dotychczasowej historii funkcjonowania rzadko stosuje podstawowy instrument tej polityki, jakim są interwencje walutowe. Jednak należy podkreślić, że wspomniane epizody interwencji były przeprowadzone na dużą skalę, sięgając rzędu 10 mld EUR, co sugeruje, iż we współczesnych realiach gospodarki światowej dla podniesienia efektywności interwencji rezerwy powinny być utrzymywane na wysokim poziomie. Próbując odpowiedzieć na pytanie, dlaczego w Eurosystemie rzadko przeprowadzane są interwencje, można wskazać dwie zasadnicze przyczyny: początkowe niejasności kompetencyjne oraz podważana często ich skuteczność. Jak podkreśla M. Frenkel, „,interwencje EBC z 2000 r. miały tylko krótkotrwały efekt, nie wpłynęły w trwały sposób na kształtowanie się kursu walutowego, zatem należy je uznać za nieefektywne" (Frenkel 2001).

Wydaje się zatem, że oficjalne uzasadnienie posiadanych przez EBC rezerw $\mathrm{w}$ aspekcie przeprowadzanych operacji interwencyjnych nie oddaje w pełni ich znaczenia. W tym miejscu należy odwołać się do coraz bardziej 
popularnej w literaturze koncepcji „siły finansowej” banku centralnego. Jest ona definiowana jako ,zakres, w jakim podmiot jest ograniczony przez sytuację finansową w realizacji celów strategicznych i polityki. Podmiot jest silny finansowo, kiedy jest nieograniczony w ich realizacji oraz słaby, kiedy ograniczenia finansowe wpływają na decyzje dotyczące realizacji celów i polityki" (Stella, Lönnberg 2008). Badania wskazują, że siła finansowa banku centralnego ma znaczenie dla skuteczności realizowanej polityki na poziomie makro poprzez jej wpływ na wiarygodność banku. Siła finansowa banku centralnego może zatem wpływać na skuteczność realizowanej polityki. Jest istotnym czynnikiem wspierania niezależności banku centralnego, pozwala na podjęcie wiarygodnego zobowiązania banku centralnego dotyczącego celu stabilności cenowej oraz wiarygodnych działań w okresach niestabilności finansowej. W przypadku banku centralnego, jakim jest EBC, budującego swoją wiarygodność i status banku niezależnego oraz będącego bankiem o silnym nastawieniu antyinflacyjnym, siła finansowa może stanowić istotny oręż wspierania tych aspektów (Vergote et al. 2010: 30-33).

Rezerwy utrzymywane przez krajowe banki centralne ESBC stanowią źródło dochodów banku centralnego i budżetu państwa (mogą stanowić podstawę do tworzenia różnych funduszy przyszłych pokoleń).Ponadto mogą służyć jako zabezpieczenie na wypadek sytuacji kryzysowych oraz do finansowania ewentualnych dalszych wpłat do EBC i instytucji międzynarodowych (np. w związku z posiadaniem SDR-ów).

W konstruowaniu bankowości centralnej Eurosystemu zastosowano podejście niskiego wyposażenia EBC w rezerwy walutowe, przy zachowaniu możliwości dokonywania dalszych wpłat przez kraje członkowskie (tzw. futhercalls). Podejście to spowodowało, że większość rezerw walutowych pozostała w narodowych bankach centralnych, stanowiąc zdecydowaną większość ogólnej puli zasobu rezerw. Udział środków przekazanych do EBC w oficjalnych aktywach rezerwowych krajów mieścił się w granicach 3-18\%, z wyjątkiem Luksemburga, który przed przystąpieniem do Eurosystemu utrzymywał niewielkie rezerwy i w związku z tym udział ten wyniósł w jego przypadku $80 \%$. Wysokim udziałem środków przekazanych do EBC w aktywach rezerwowych charakteryzowały się Włochy (18\%), z kolei niskim udziałem Cypr (3\%), Słowenia (4\%), Austria i Irlandia (po 7\%) (Grabczyński et al. 2008).

Zgodnie ze Statutem, wielkość rezerw walutowych EBC w momencie ich utworzenia została ustalona na poziomie 50 mld EUR. Wysokość transferu rezerw z narodowych banków centralnych została ustalona jako proporcjonalna do udziału kraju w kapitale subskrybowanym EBC. Wielkość rezerw walutowych EBC w odniesieniu do krajowych zasobów rezerwowych jest skromna. Na koniec 2010 r. całkowite zasoby rezerw ESBC wynosiły 591 mld EUR, z czego 534 mld EUR było w posiadaniu krajowych banków centralnych. Na koniec 2010 r. rezerwy walutowe EBC stanowiły około 57 mld EUR, z czego 17 mld było 
w złocie, 0,4 mld w SDR-ach, zaś pozostała część w USD i JPY. Na wzrost poziomu rezerw wpłynęły przede wszystkim zmiany kursowe oraz zysk kapitałowy, jednak należy mieć także na uwadze czynnik strukturalny, wynikający z kolejnych rozszerzeń UGiW, oznaczających podwyższanie kapitału subskrybowanego i skali transferu rezerw z narodowych banków centralnych.

W świetle dotychczasowych rozważań wydaje się, że podejście do budowy rezerw walutowych w UGiW było racjonalne - chodziło o wyposażenie EBC w pewien zasób rezerw, mający stanowić element jego „siły finansowej”, przy świadomości niewielkiej ich użyteczności, wynikającej z rzadko przeprowadzanych operacji interwencyjnych i zagwarantowaniu sobie prawa do ich uzupełniania w sytuacji konieczności zwiększenia efektywności interwencji lub podjęcia innych działań.

Od strony technicznej należy wspomnieć o zmianie zarządzania portfelem rezerw na skutek zmiany roli rezerw dla krajów członkowskich UGiW. Spadek kryterium płynności środków w strategii zarządzania powoduje jednoczesny wzrost roli kryterium maksymalizacji stopy zwrotu, co może prowadzić do pogłębienia się procesu dywersyfikacji rezerw.

Zarządzanie portfelem rezerw EBC polega na centralizacji funkcji zarządzania ryzykiem oraz decentralizacji operacji inwestycyjnej w ramach przyjętych centralnie benchmarków. Cele, którymi kieruje się EBC przy zarządzaniu rezerwami walutowymi to (w kolejności odpowiadającej ich ważności): płynność, bezpieczeństwo i rentowność (EBC 2012).W EBC zostały stworzone dwa portfele inwestycyjne: portfel dolarowy i jenowy. W celu zwiększenia wydajności operacji inwestycyjnych EBC, od 2006 r. funkcjonuje tzw. model specjalizacji walutowej, polegający na dobrowolnym przyjmowaniu przez narodowe banki centralne (pojedynczo lub w grupie) w imieniu EBC w zarządzanie jednego (lub dwóch) z subportfeli. Na koniec $2010 \mathrm{r}$. funkcjonowało 9 portfeli dla zarządzania aktywami dolarowymi oraz 6 dla aktywów jenowych.

Dotychczasowa kompozycja portfela rezerw EBC cechuje się wzrostem udziału aktywów JPY i spadkiem udziału aktywów USD. O ile w 1999 r. aktywa dolarowe i jenowe stanowiły odpowiednio 90\% i 10\% portfela należności dewizowych, o tyle na koniec 2009 r. wynosiły odpowiednio $78 \%$ i $22 \%$. Istotny wzrost aktywów jenowych był konsekwencją wyprzedaży złota, prowadzonej głównie w latach 2005-2009, a także osłabiania USD względem JPY.

\section{PODSUMOWANIE}

Jak wynika z przeprowadzonych rozważań, EBC ma niewielki poziom rezerw walutowych, jednak uwzględniając rezerwy utrzymywane na poziomie narodowym, całościowy ich zasób plasuje UGiW w grupie kluczowych global- 
nych posiadaczy rezerw. Zastosowany ustawowo manewr w postaci rozdzielenia funkcji obu puli rezerw i możliwości doposażenia EBC w rezerwy należy ocenić jako spójny z teoretycznymi przewidywaniami odnośnie mniejszej użyteczności rezerw krajów rozwiniętych, funkcjonujących dodatkowo w warunkach unii walutowej. Obserwowany w ostatniej dekadzie wzrost rezerw nie wynika z intencjonalnej polityki akumulacji, lecz z pozytywnych efektów kursowych oraz wzrostu wartości portfela. Zjawisko to jest obserwowalne także w przypadku innych wiodących banków centralnych krajów rozwiniętych, z wyjątkiem Szwajcarii i Japonii, gdzie mieliśmy do czynienia z polityką intencjonalnego akumulowania rezerw.

\section{BIBLIOGRAFIA}

Bogołębska J. (2013), Nierównowagi globalne a stabilność międzynarodowego system walutowego. Analiza na przykładzie akumulacji rezerw walutowych, Wydawnictwo Uniwersytetu Łódzkiego, Łódź.

EBC (2012), Raport Roczny 2012, https://www.ecb.europa.eu/pub/pdf/annrep/ar2012pl.pdf?f7a7ef9689e62779cefdb3436ff35a4e (dostęp: 10.05.2014).

Frenkel M. (2001), The foreign exchange market interventions of the ECB, "PSL Quarterly Review", Vol. 54, No. 218.

Goldberg L., Hull C., Stein S. (2013), Do industrialized countries hold the right foreign exchange reserves?, "Current Issues in Economics and Finance", Vol. 19, No. 1.

Grabczyński J., Hylewski J., Roy A., Szafarczyk E., Zielińska M. (2008), Skutki integracji walutowej dla procesu zarzadzania rezerwami walutowymi NBP, https://www.nbp.pl/badania/seminaria_bise/GrabczynskiO.pdf (dostęp: 10.05.2014).

Henning C. (2007), Organizing foreign exchange intervention in the Euro Area, "Journal of Common Market Studies", Vol. 45, No. 2.

Munro A., Reddell M. (2012), Foreign currency reserves: Why we hold them influences how we fund them, "Reserve Bank of New Zealand Bulletin", Vol. 75, No. 3.

Pihlman J., van der Hoorn H. (2010), Procyclicality in Central Bank Reserve Management: Evidence from the Crisis, IMF Working Paper, WP/10/150.

Przestanki oceny poziomu rezerw walutowych (2003), „Materiały i Studia NBP”, nr 170.

Stella P, Lönnberg Å. (2008), Issues in Central Bank Finance and Independence, IMF Working Paper, WP/08/37.

Vergote O., Studener W., Efthymiadis I., Merriman N. (2010), Main drivers of the ECB financial accounts and ECB financial strength over the first 11 years, ECB Occasional Paper Series, No. 111, May.

Wójcik C. (2005), Przesłanki wyboru systemów kursowych, Szkoła Główna Handlowa w Warszawie, Warszawa. 
Joanna Bogotębska

THE LEVEL, MOTIVES AND FUNCTIONS OF FOREIGN RESERVES

OF THE DEVELOPED COUNTRIES. ANALYSIS WITH A PARTICULAR FOCUS

ON THE EUROPEAN SYSTEM OF CENTRAL BANKS

\begin{abstract}
The article concentrates on analysis of motives, level and functions fulfilled by foreign exchange reserves in developed countries, with special emphasis put on the dual system of reserves within Economic and Monetary Union (EMU). The foreign exchange reserves of industrial countries have grown up during the last decade. However, in the case of EMU this growth have been not due to the intentional policy of the central bank (as in the case of Japan and Switzerland), but due to positive changes of exchange rates and rates of return.
\end{abstract}

Keywords: foreign reserves, the European System of Central Banks. 